\title{
The Mediating Effect of the Knowledge Management Process to the Firm's Performance: A Resource-Based View
}

\author{
Nikolaos Theriou ${ }^{1}$, Vassilis Aggelidis, Georgios Theriou
}

\begin{abstract}
:
The purpose of this paper is to explore the relationship between the two most important perspectives of the firm, the $R B V$ and the $K B V$, by examining the relative impact of firmspecific assets and knowledge capabilities on the firm's competitive advantage. A composite model is proposed which elaborates upon both perspectives causal logic with respect to the conditions relevant for the firm success. Empirical findings suggest that firm-specific assets and knowledge capabilities effects are both important determinants of the firms' performance. Moreover, the findings suggest that knowledge capabilities behave like dynamic capabilities leading to the continuous improvement-renewal of the firm-specific resources and capabilities which, in turn, affect performance directly or indirectly through their effect on strategy configuration.
\end{abstract}

Key Words: Strategic Management, Resource-Based View, Knowledge-Based View, Knowledge Management, Structural Equation Modelling, Confirmatory Factor Analysis

JEL Classification: D73, K12

\footnotetext{
${ }^{1}$ Correspondence to: N. G. Theriou, Eastern Macedonia \& Thrace Institute of Technology, Agios Loukas, Kavala 65404, Greece, telephone: 00302510462371, fax: 00302510462148, email: ntheriou@teiemt.gr
} 


\section{Introduction}

The dominant paradigms in the field of strategic management during the 1980s and 1990s were the competitive forces approach (Porter, 1980) and the resource-based perspective (Penrose, 1959; Rumelt, 1984; Teece, 1984; Wernerfelt, 1984; Barney, 1991). The former emphasizes the actions a firm can take to earn economic rents by creating privileged market or industry positions against competitive forces. The latter emphasizes building competitive advantage through capturing economic rents stemming from fundamental firm-level efficiency advantages.

Although there are apparent conflicting ideas between these two paradigms, in reality both can co-exist and shape actual firm behaviour (Spanos and Loukas, 2001). In fact, according to Wernerfelt (1984), Porter's framework and the resourcebased approach constitute the two sides of the same coin. This view about the complementarity-compatibility of these two approaches in explaining a firm's performance was theoretically recognized (Barney and Zajac, 1994; Amit and Schoemaker, 1993; Peteraf, 1993, Barney, 1992; Barney and Griffin, 1992; Mahoney and Pandian, 1992; Conner, 1991) and empirically tested (Schmalensee, 1985; Hansen and Wernerfelt, 1989; Rumelt, 1991; McGahan and Porter, 1997; Mauri and Michaels, 1998; Spanos and Loukas, 2001) by many researchers.

In recent years many studies on the status, evolution, and/or trends of the resourcebased view (RBV) have been published (Barney, 2001a, 2001b; Mahoney, 2001; Makadok, 2001; Priem and Butler, 2001; Phelan and Lewin, 2000; Hoskisson et al., 1999; Williamson, 1999). One of the most recent studies (Acedo, Barroso and Galan, 2006), adopting the bibliometric methodology (Zitt and Bassecoulard, 1996; Ahlgren, Jarneving, and Rousseau, 2003), analyzes the so called resource-based theory (RBT)'s heterogeneity and identifies three main trends coexisting within it: the resource-based view (RBV) (e.g., Barney, 1991 and Wernerfelt, 1984), including some representative works of the dynamic capability perspective (Teece, Pisano, and Shuen, 1997), the knowledge-based view (KBV) (e.g., Kogut and Zander, 1992 and Grant, 1996a) and the relational view (RV) (e.g., Dyer, 1996).

However, none of these studies has empirically tested the degree of compatibility or complementarily between those different approaches. The present study attempts to empirically test two of the most common and influential perspectives, the RBV and the KBV. A composite framework, including both theoretical perspectives, will be proposed and tested with real data from Greece.

The following section presents the theoretical background of the two perspectives with respect to sustainable competitive advantage as well as the rationale for the development of a composite model. Section three describes and presents the model development and hypotheses and section four presents the empirical analysis and 
The Mediating Effect of the Knowledge Management Process to the Firm's Performance: A Resource-Based View

results. Finally, the paper concludes with a discussion of findings and with directions for future research.

\section{Theoretical Background}

\subsection{RBV Perspective}

The resource-based view comprises a rising and dominant area of the strategy literature which addresses the question of an organization's identity and it is principally concerned with the source and nature of strategic capabilities. The resource-based perspective has an intra-organisational focus and argues that performance is a result of firm-specific resources and capabilities (Barney, 1991; Wernerfelt, 1984).

The basis of the resource-based view is that successful firms will find their future competitiveness on the development of distinctive and unique capabilities, which may often be implicit or intangible in nature (see Teece et al., 1991). Thus, the essence of strategy is or should be defined by the firm's unique resources and capabilities (Rumelt, 1984). Furthermore, the value creating potential of strategy, that is the firm's ability to establish and sustain a profitable market position, critically depends on the rent generating capacity of its underlying resources and capabilities (Conner, 1991).

For Barney (1991) if all the firms were equal in terms of resources there would be no profitability differences among them because any strategy could be implemented by any firm in the same industry. The underlying logic holds that the sustainability of effects of a competitive position rests primarily on the cost of resources and capabilities utilized for implementing the strategy pursued. This cost can be analyzed with reference to strategic factor markets (Barney, 1986a), that is markets where necessary resources are acquired. It is argued that strategic factor markets are imperfectly competitive, because of different expectations, information asymmetries and even luck, regarding the future value of a strategic resource.

However, a serious resource-based approach omission is that there is not a comprehensive framework that shows how various parts within the organization interact with each other over time to create something new and unique (Nonaka and Takeuchi, 1995). The resource based view (RBV) suggests that competitive advantage and performance results are a consequence of firm-specific resources and capabilities that are costly to copy by other competitors (Barney, 1986a, 1986b, 1991; Wernerfelt, 1984; Rumelt 1987; Thalassinos et al., 2012). These resources and capabilities can be important factors of sustainable competitive advantage and superior firm performance if they possess certain special characteristics. They should 
be valuable, increasing efficiency and effectiveness, rare, imperfectly imitable and non-substitutable (VRIN) (Barney 1991).

The implication of this argument is that efficiency rents stemming from such resources and capabilities could be categorized into two, interrelated dimensions (Spanos and Lioukas, 2001):

(a) 'pure' rents (Collis, 1994) stemming directly from the efficient implementation of the given strategy currently pursued; it indicates that the more unique combination of resources the organization possesses in relation to rivals the higher is its performance. In this case firm effects are independent of strategy, and

(b) 'indirectly' from enabling the firm to conceive and develop its strategy configuration; the more resources the better the ability of the firm for a strategy that fits better market demand and results in higher customers' utility.

\subsection{KBV Perspective}

Although Alchian and Demsetz (1972) observed that efficient production with heterogeneous resources is a result not of having better resources but in knowing more accurately the relative productive performances of those resources, the emergence of the knowledge-based view (KBV) came much later.

This approach considers firms as bodies that generate, integrate and distribute knowledge (Narasimha, 2000; Miller 2002). The ability to create value is not based as much upon physical or financial resources as on a set of intangible knowledgebased capabilities. According to the KBV competitive success is governed by the capability of organisations to develop new knowledge-based assets that create core competencies (Pemberton and Stonehouse, 2000). Fundamental to the KBV of the firm is the assumption that the critical input in production and primary source of value is knowledge (Grant, 1996a).

In the knowledge-based view, analysis of capabilities has incorporated human, social and organizational resources next to economic and technical resources. Firms that possess stocks of organizational knowledge associated with value that could be described as uncommon or idiosyncratic, stand a good chance of generating sustaining high returns (Raft and Lord, 2002).

However, Leonard-Barton (1992) does warn that there is a dual nature within these knowledge-based stocks-capabilities, which can have as a result the alteration of the prior beneficial resources to potent core rigidities or performance inhibitors, in other words, what is a capability today may become a liability tomorrow. This concern 
that capabilities may become rigidities emphasizes the importance of understanding the processes of knowledge creation and development (Croom and Batchelor, 1997). Within KBV, two large subgroups can be identified (Acedo, Barroso, and Galan, 2006): One subgroup, which could be considered as closer to the RBV, asserts that knowledge is the most important strategic resource for organizations (Conner and Prahalad, 1996; Grant, 1996a; Kogut and Zander, 1992). Although the RBV recognizes the importance and role of knowledge in firms achieving a competitive advantage (Wernerfelt, 1984; Barney, 1991, 1996) knowledge-based theorists argue that RBV does not go far enough. Specifically, the RBV treats knowledge as a generic resource, rather than having special properties, and subsequently, does not make any distinction between different types of knowledge-based capabilities (Kaplan et al. 2001).

The other subgroup shares Spender's $(1989,1992,1996)$ position on the importance of collective knowledge-a knowledge that is tacit and social. This stream offers insight into different types of behaviour, inherent limitations of individuals, and the development of firms' knowledge-based activities and routines, assuming that individuals are limited by their bounded rationality (March and Simon, 1958). As a consequence of this limitation, not all of the firm's knowledge can be found in any one person's head and, therefore, it is distributed across its members.

This difference is very well explained by Grant (1996a) who believes that knowledge resides at an individual level, thereby making knowledge integration the essential function for a firm:

'Most research into organizational learning (Levitt and March, 1988; Huber, 1991) and the knowledge-based view of the firm (Spender, 1989; Nonaka, 1991, 1994) focuses upon the acquisition and creation of organizational (new) knowledge. My approach is distinguished by two assumptions: first, that knowledge creation is an individual activity; second, that the primary role of firms is in the application of existing knowledge to the production of goods and services' (Grant, 1996a: 112).

This approach ignores the concept of organizational knowledge and emphasizes the role of the individual in creating and storing knowledge. It is very similar with Simon's observation that 'all learning takes place inside individual human heads; an organization learns in only two ways: (a) by the learning of its members, or (b) by ingesting new members who have knowledge the organization didn't previously have (Simon, 1991: 125).

Thus, unlike Spender (1992), who analyzes the dual role of firms in knowledge generation and knowledge application, Grant's emphasis is on the firm as an institution for knowledge application devising mechanisms for integrating individuals' specialized knowledge (Grant, 1996a). 
Albeit there are different approaches of the KBV, the most accepted way of building distinctive capabilities and core competences within firms is through experience accumulation, knowledge articulation and codification (Macher and Mowery, 2006; Zollo and Winter, 2002; Nonaka, 1994; Zander and Kogut, 1995) or through the so called knowledge management (KM) processes of creating, acquiring, storing, sharing and deploying knowledge (Pemberton and Stonehouse, 2000). The extent to which a capability is 'distinctive' depends upon the firm and its employees in creating, acquiring, storing, sharing and deploying all necessary generic and specific knowledge that will give them a competitive advantage. Longevity of competitive advantage depends upon the inimitability of the capabilities which underlie that advantage (Barney, 1991).

Although there is recognition that knowledge is a key business asset, organisations are still in the early stages of understanding the implications of KM. KM is slowly becoming an integral business function to them (Metaxiotis et al., 2005). Previous research (Davenport and Prusak, 1998; Liebowitz, 2000) has shown that a knowledge-based company possesses knowledge that allows it to manoeuvre with intelligence and creativity giving it a special advantage. For Davenport and Prusak (1998) knowledge is the only source of a sustainable competitive advantage.

However, since knowledge is not directly observable or measurable, then, it becomes a construct whose existence and properties can only be inferred through firm capabilities that are manifested in observable action (Stehr, 1992). This differentiates knowledge from resources, which can be identified without observable action. Different actions can be ascribed to different capabilities. Thus, a specific 'constellation of actions' represents a specific set of capabilities inside the firm and implies the existence of specific knowledge that is required to exercise these capabilities (Kaplan et al., 2001). Under this reasoning we could consider any function of the KM process (formal or informal), leading to the building of successful distinct capabilities or core competencies, as a 'prerequisite or first-order KM capability'. Consequently, for a firm to have a sustainable competitive advantage 'KM capabilities' should be built first in order to be able to create all other necessary distinct capabilities and/or core competencies in time.

Similarly, Kale and Singh (1999) believe that knowledge management processes represent a vital core competence that can be leveraged to build other strategic capabilities or "second order" dynamic capabilities (Zollo and Winter, 2002) as, for example, the capability to manage phenomena such as acquisitions, corporate restructuring, etc., (Thalassinos and Zampeta, 2012).

Sher and Lee (2004) argue that KM includes three main functions: Knowledge creation, accumulation and sharing. Knowledge creation includes innovation, knowledge accumulation includes collecting new knowledge, codifying it and 
combining new and old knowledge, and knowledge sharing allows for diffusion of skills, experience and knowledge throughout the organisation.

Lee et al. (2005) add two more functions: knowledge utilization and knowledge internalization. Knowledge utilization can occur at all levels of management activities in firms: one of the popular forms of knowledge utilization is to adopt the best practice from other leading organizations, uncover relevant knowledge, and apply it. Knowledge internalization may occur when individual workers discover relevant knowledge, obtain it and then apply it. Therefore, internalization may give rise to new knowledge. In this way, it provides a basis for active knowledge creation. Other researchers (Alavi and Leidner, 2001; Nielsen, 2006) suggest the following eight basic functions of KM, which are quite similar to those five mentioned above: knowledge creation, knowledge acquisition, capturing and articulating knowledge, knowledge assembly, knowledge sharing, knowledge integration and recombination, knowledge leverage, and, finally, knowledge application and exploitation.

If we think knowledge and knowledge management processes as 'prerequisite or first-order KM capabilities', then the implication of this argument is that efficiency rents stemming from such KM capabilities could be categorized into three, interrelated dimensions:

(a) 'pure' rents (Collis, 1994) stemming directly from the efficient implementation of the given strategy currently pursued; it indicates that the more unique combination of KM capabilities the organization possesses in relation to rivals the higher is its performance (in this case firm effects are independent of strategy)

(b) 'indirectly' from enabling the firm to conceive and develop its strategy configuration; the more KM capabilities the better the ability of the firm for a strategy that fits better market demand and results in higher customers' utility, and

(c) 'indirectly' through the improvement of existing or the creation of new organizational, marketing and technical capabilities. These latter indirect effects result from KM capabilities that resemble Teece et al.'s (1997) notion of dynamic capabilities defined as those that reflect the firm's ability to achieve new and innovative form of competitive advantage.

All the above result in a fundamental complementarily between these two theoretical approaches, $\mathrm{RBV}$ and $\mathrm{KBV}$, which lead to the construction of a composite framework trying to compare and contrast the two perspectives' causal logic of rent generation. This framework is justified on the basis of three reasons: (a) the two perspectives are complementary in explaining the sources of competitive advantage through their effects (direct and indirect) on performance; (b) both perspectives seek 
to explain the same phenomenon of sustained competitive advantage, and (c) the unit of analysis (i.e., the firm) is the same in both cases.

\section{Model Development and Hypothesis}

In this research $\mathrm{RBV}$ and $\mathrm{KBV}$ constitute the two perspectives the impact of which on firm performance will be examined. The proposed composite model is presented schematically in figure 1. The proposed model includes three effects: (i) strategy or "utility" direct effects that sustain the necessary condition for achievement of higher performance, (ii) firm-specific assets' direct and indirect effects and (iii) KM capabilities' direct and indirect effects, that constitute the sufficient conditions for the achievement of sustainable competitive advantage or else sustainable performance.

\subsection{Strategy Effects}

Since customer and market needs are the primary keys for the maximization of profitability, managers have to develop and apply such strategies that maximize customers' utility. This occurs by differentiated products or by lower cost production. Market demand, besides, reflects customer needs and demonstrates firm's profitability. This is the reason that strategy effects that take into consideration market demand and consequently customers utility, are named otherwise "utility effects". However, although utility effects provide the necessary condition for high performance, above industry's average effects, coming from specific unique resources and capabilities, are needed for its sustainability (Spanos and Lioukas, 2001). Strategy or "utility" (direct) effects are shown by $\xi 1$ in the model.

\subsection{Firm Assets Effects}

As it has been already discussed, according to the RBV, the existence of unique resources leads to sustainable competitive advantage. Schematically, two efficiency effects are appeared (Spanos and Lioukas, 2001). One of them, $\xi 2$, is directly related to firm performance. It indicates that the more unique combination of resources the organization possesses in relation to rivals the higher is its performance. In this case firm effects are independent of strategy. In parallel with direct firm assets effects, there are indirect effects, too. Path $\xi 3$ explains the perception that the more resources/capabilities the better the ability of the firm for a strategy that fits better market demand and results in higher customers' utility. These indirect firm assets effects could be estimated as $\xi 1 * \xi 3$. 
The Mediating Effect of the Knowledge Management Process to the Firm's Performance:

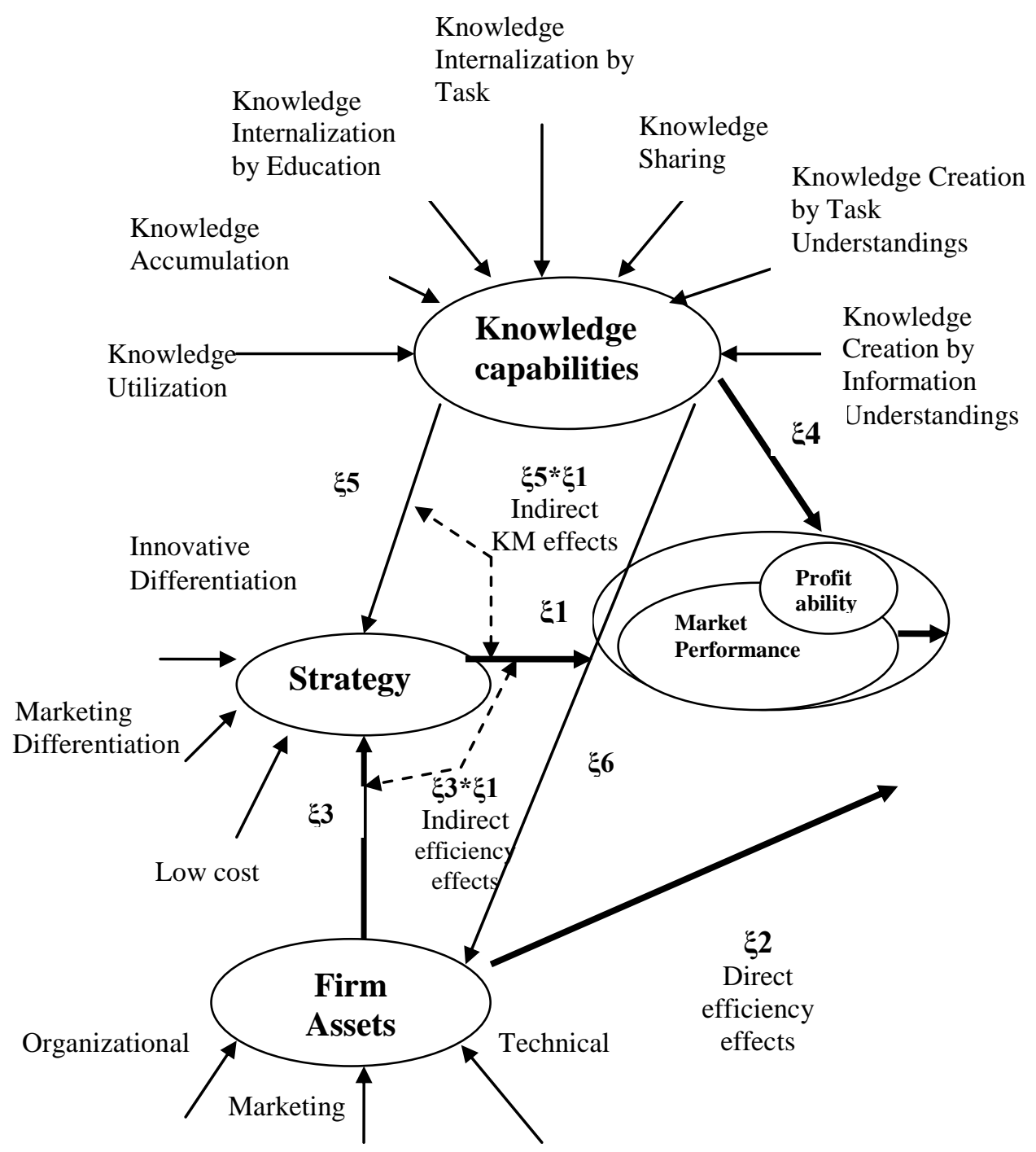

Figure 1. The proposed conceptual framework

\subsection{KM Capabilities Effects}

In accordance with KBV, KM capabilities are the primary responsible factors for the achievement of sustainable competitive advantage. These include all knowledge acquisition, creation, capture, storage, diffusion and transfer capabilities, which transform individual to group and, finally, to organizational knowledge. KM capabilities affect performance with two effects, direct and indirect, which affect the 
firm performance in a similar way with the firm-specific assets (i.e., the unique resources and capabilities). Hence, KM direct effect is denoted as $\xi 4$ and its indirect effect (through its effect on strategy) as $\xi 5$. These indirect knowledge effects could be estimated as $\xi 1 * \xi 5$.

However, KM capabilities also affect performance through a second indirect effect on firm-specific resources and capabilities, denoted as $\xi 6$. This KM capabilities' indirect effect leads to the continuous improvement and/or renewal of the firmspecific resources and capabilities which, in turn, affect performance directly ( $\xi 2)$ or indirectly through their affect on strategy $(\xi 3)$.

Consequently, two hypotheses are formulated:

Hypothesis 1: Firm performance depends on competitive advantage through strategy configuration or utility effects (as a necessary condition) the sustainability of which depends on direct and indirect effects stemming from available capabilities.

Hypothesis 2: Firm performance depends on competitive advantage through strategy configuration or utility effects (as a necessary condition) the sustainability of which depends on direct and indirect effects stemming from available KM capabilities.

\subsection{Performance}

Each research uses different performance measures analogous to its needs. For the specific proposed framework the measures of firm performance are the same used by Spanos and Lioukas (2001). They have adopted two dimensions of performance, profitability and market performance, proposed by Venkatraman and Ramanujam (1986). The first one reflects its internal success revealed by financial statements and the second one refers to external accomplishments related to market position, such as market share or sales. We also assume in our model, as Spanos and Lioukas (2001) did, a positive relationship between market performance and profitability (the first one affects the second) as various empirical researches have shown in the past.

\section{Method}

\subsection{Sample and Data Collection}

A structured survey was conducted with a target population consisting of the 500 most profitable manufacturing firms in Greece. From those firms only the 487 were selected on the following grounds (Spanos and Lioukas, 2001): (a) they were independent or single business units so that the effects of strategy, capabilities and 
knowledge to be examined independent of the effects of corporate level considerations, and (b) they were firms employing at least twenty employees in order to ensure a minimum operating structure.

Before conducting the main survey, a pretest was performed. The research instrument was pretested, after in depth discussions with academics and professionals, with CEOs from 5 manufacturing firms. After some minor modifications the final questionnaire was emailed to CEOs together with a letter explaining the purpose of the study and assuring anonymity. A follow up questionnaire was sent to those who did not return the initial questionnaire after a three weeks waiting period. 204 questionnaires were returned, for a gross response rate of $41.89 \%$. It should be noted that many managers declined to participate due to time constrains or company privacy concerns. Out of these a total of 14 questionnaires were found invalid due to an insufficiently completed survey. A total of 190 responses were appraised as suitable for our analysis giving an effective response rate of $39 \%$. The average firm size is 126 employees (median 62).

To test whether our respondents were different from the non-respondents we examined if there were any differences in the means of all variables used in the study between early and late respondents. The rationale behind such an analysis is that late respondents (i.e., sample firms in the second wave) are more similar to the general population than the early respondents (Armstrong and Overton, 1977). There was no statistically significant difference found in the means of all variables used in this study. Hence it appears that non-response bias was not an issue in this study.

The study was conducted in Greece between June and October 2007.

\subsection{Determination of the Variables}

The main objective of this study is to investigate the dual impact of resource based view and knowledge based view in firm performance. More analytically, the constructs that need to be measured through the completion of the constructed questionnaire are the following: the strategy followed, the firm-specific assets used, the knowledge capabilities used and the firm's performance. For this reason, firm's performance is defined as the dependent variable while strategy, firm assets and knowledge capabilities are the independent variables. All constructs included in the questionnaire were measured with multiple-item five-point Likert scale (see Appendix 1 for details).

Measures of Porter's generic strategies were derived and adapted from Dess and Davis' (1984) and Miller's (1988) studies. 11 items were used to describe three types of strategy (Spanos and Lioukas, 2001): innovative differentiation, marketing differentiation and low cost. The questionnaire asks questions regarding the extent of 
usage of specific competitive methods (tactics) relevant to each of the three generic strategies (1: much less than its competitors...5: much more than its competitors). Concerning the measurement of the complex construct of "firm assets", we used those items proposed by Spanos and Lioukas (2001): CEOs were asked to indicate the extent to which specific organizational (7 items), marketing (4 items), and technical (3 items) capabilities (firm assets) constitute particular strengths relative to competition (1: much weaker than its competitors...5: much stronger than its competitors).

For the measurement of knowledge management capabilities we used the items proposed by Lee et al. (2005), where knowledge management capabilities are separated into five distinctive categories. Specifically, CEOs were asked to indicate the extent to which specific knowledge creation (7 items), accumulation (7 items), sharing (4 items), utilization (6 items), and internalization ( 9 items) capabilities constitute particular strengths relative to competition (1: much weaker than its competitor to 5: much stronger than its competitors).

Finally, for the measurement of firm's performance, the metrics used by Spanos and Lioukas (2001) were adopted. Performance is operationalised as a two-dimensional construct, including profitability and market performance (Woo and Willard, 1983; Venkatraman and Ramanujam, 1986). The former was gauged with three perceptual items reflecting return on equity, return on own capital and net profits relative to competition, whereas the later was measured with absolute sales volume, growth in sales volume, market share, and growth in market share. On the other hand, profitability is measured by return on equity, return on own capital and net profits. CEOs were asked to indicate, for each of the above mentioned market and profitability measures, their firm's performance relative to competition for the last three years $^{2}$ (1: much below the average...5: much above the average).

Since the study addresses to SMEs it is quite difficult for the majority of firms their answers concerning performance metrics to be evaluated as long as there are not enough reliable financial data for all of them. Moreover, almost half of the questionnaires were returned anonymously. Unfortunately, various researches confirm that financial data stemming from SMEs are not considered of great validity (Dess and Robinson, 1984; Powell and Dent-Micallef, 1997; Thalassinos et al., 2012). For instance, in Greece, firms are not forced by law to record and publish

2 Performance is indicated by taking into account the last three years of the firm's operations and not just the last one, thus the average performance of the last three years is calculated in relation to competition in order to avoid any temporary fluctuations. 
The Mediating Effect of the Knowledge Management Process to the Firm's Performance:

A Resource-Based View

$\mathrm{R} \& \mathrm{D}$ expenses in financial statements, although they are considered to be the most reliable indicator of innovative differentiation strategy. To these problems it should be added the difficulty of identifying and measuring firm and knowledge capabilities.

\section{Results}

The evaluation of the measurement and structural model play the major role for the estimation of the overall model. The measurement model describes the connection between the latent variables (complex constructs) and their manifest indicators (items or questions) through the calculation of the first (i.e., the manifest) and second (i.e., of the latent) order loadings of both dependent and independent variables. Results that are presented in the Appendix 1 indicate that most of the constructs exceed the cut-off point of 0.5 .

The structural model describes the causal relationships (connections) among the latent variables (i.e., the complex constructs) and the general fit of the whole model. The statistical package AMOS was used for the estimation of both the first and second order loadings, through confirmatory factor analysis, and the metrical relations among the latent variables of the model via path analysis. Table 1 summarizes the results of direct effects of utility effects, firm assets and knowledge capabilities ( $\boldsymbol{\xi} \mathbf{1}, \boldsymbol{\xi} \mathbf{2}$ and $\boldsymbol{\xi} \mathbf{4}$ respectively) on performance (market performance and profitability). Table 2 presents the indirect impact of firm assets and knowledge capabilities on strategy, explaining the routes of $\boldsymbol{\xi} \mathbf{3}$ and $\xi 5$ respectively. Table 3 presents the total effects of the constructs on firm performance.

Table 1: Standardized Direct Effects

\begin{tabular}{|c|c|c|c|}
\hline Parameter $($ from $\rightarrow$ to $)$ & Strategy & $\begin{array}{c}\text { Market } \\
\text { Performance }\end{array}$ & Profitability \\
\hline Utility Effects $(\xi 1)$ Strategy $\rightarrow$ & 0.000 & 0.315 & 0.000 \\
\hline $\begin{array}{l}\text { Direct Efficiency Effects of firm } \\
\text { assets }(\xi 3) \text { and }(\xi 2) \text {. Firm assets } \rightarrow\end{array}$ & 0.395 & 0.424 & 0.000 \\
\hline $\begin{array}{l}\text { Direct Efficiency Effects of } \\
\text { knowledge capabilities }(\xi 5) \text { and }(\xi 4) \text {. } \\
\text { Knowledge capabilities } \rightarrow\end{array}$ & 0.456 & 0.279 & 0.000 \\
\hline Market Performance $\rightarrow$ & 0.000 & 0.000 & 0.852 \\
\hline
\end{tabular}


Table 2: Standardized Indirect Effects

\begin{tabular}{|l|c|c|c|}
\hline Parameter (from $\rightarrow$ to) & Strategy & $\begin{array}{c}\text { Market } \\
\text { Performance }\end{array}$ & Profitability \\
\hline $\begin{array}{l}\text { Indirect Utility Effects } \\
\text { Strategy } \rightarrow\end{array}$ & 0.000 & 0.000 & 0.269 \\
\hline $\begin{array}{l}\text { Indirect Effects of firm assets } \\
(\xi 3 * \xi \mathbf{1}) \\
\text { Firm assets } \rightarrow\end{array}$ & 0.000 & $\mathbf{0 . 1 2 5}$ & $\mathbf{0 . 4 6 7}$ \\
\hline $\begin{array}{l}\text { Indirect Effects of knowledge } \\
\text { capabilities ( } \mathbf{5} * \boldsymbol{\xi} \mathbf{1}) \text { Knowledge } \\
\text { capabilities } \rightarrow\end{array}$ & 0.000 & $\mathbf{0 . 1 4 4}$ & $\mathbf{0 . 3 6 0}$ \\
\hline
\end{tabular}

Table 3: Standardized Total Effects (Direct + Indirect Effects)

\begin{tabular}{|l|c|c|c|}
\hline Parameter (from $\rightarrow$ to) & Strategy & $\begin{array}{c}\text { Market } \\
\text { Performance }\end{array}$ & Profitability \\
\hline Utility Effects Strategy $\rightarrow$ & 0.000 & $\mathbf{0 . 3 1 5}$ & $\mathbf{0 . 2 6 9}$ \\
\hline $\begin{array}{l}\text { Efficiency Effects of firm assets } \\
\text { Firm assets } \rightarrow\end{array}$ & $\mathbf{0 . 3 9 5}$ & $\mathbf{0 . 5 4 8}$ & $\mathbf{0 . 4 6 7}$ \\
\hline $\begin{array}{l}\text { Direct Efficiency Effects of } \\
\text { knowledge } \\
\text { Knowledge capabilities } \rightarrow\end{array}$ & $\mathbf{0 . 4 5 6}$ & $\mathbf{0 . 4 2 3}$ & $\mathbf{0 . 3 6 0}$ \\
\hline Market Performance $\rightarrow$ & 0.000 & 0.000 & $\mathbf{0 . 8 5 2}$ \\
\hline
\end{tabular}

The overall model shows a chi-square value of $33.20(\mathrm{df}=29)$, which is quite high in relation to the degrees of freedom $\left(\mathrm{X}^{2} / \mathrm{df}=1.145>1\right.$ and $\left.<2\right)$, and has a $\mathrm{p}$-value $>$ 0.01 . This, alone, indicates an excellent fit to data. Additionally, another commonly used fit index is the Comparative Fit Index (CFI), which has a value of 0.997, while the Goodness-of-fit Index (GFI) has a value of 0.961 , both indicating a perfect adaptation since they are close to 1. Moreover, Root Mean Square Residual (RMR) with 0.015 and Root Mean Square Error of Approximation (RMSEA) with 0.031 indicate acceptable model fit, because they are less than $0.1(<0.1)$. All model fit indexes are presented in Table 4. 
The Mediating Effect of the Knowledge Management Process to the Firm's Performance:

A Resource-Based View

101

Table 4: Model Fit Summary

\begin{tabular}{|c|c|c|c|c|c|}
\hline $\mathrm{X}^{2} / \mathrm{df}$ & $\mathrm{p}$-value & CFI & GFI & RMR & RMSEA \\
\hline $33.20 / 29=1.145$ & .270 & .997 & .961 & .015 & .031 \\
\hline
\end{tabular}

Strategy Effects

According to figure 2, results indicate that about $46 \%$ of strategy configuration is influenced by knowledge capabilities and $39 \%$ by firm assets, while $65 \%$ is influenced by both (KM capabilities and firm assets). Strategy seems to affect positively, and indeed strongly, firm performance but only through market performance (.32) and not profitability. Its indirect impact on firm profitability is lower $(.32 * .85=.27)$. The strong positive direct effect of strategy on market performance (.32) and the positive indirect effect of strategy on profitability (.27) confirm that these strategy effects constitute a necessary condition for above normal firm performance, i.e., firm strategy is consistent with hypotheses 1 and 2 because it appears to influence positively and significantly firm success.

\section{Firm Effects}

Results have shown a strong positive relationship between market performance and firm assets (.42), which is actually the strongest relatively to the rest two complex constructs of strategy (.32) and knowledge capabilities (.28). This positive relationship is strong for both direct effects (.424, table 1) and total effects $(.424+.125=\mathbf{. 5 4 8}$, table 3$)$. Consequently, the sustainability of competitive advantage depends on the possession of unique resources. Firm assets' indirect effect to market performance is .125 (route $\xi 3 * \xi 1$ in table 2), while to firm profitability is .467 , which again consists the higher value among the other constructs and seems to influence mostly the firm performance. Thus, these results lead us to the acceptance of hypothesis 1 .

\section{Knowledge Effects}

According to the results, the effect of knowledge capabilities on performance is really strong and positive. The total impact of knowledge assets on market performance is .423 (table 3), although their direct effect is only .279 (table 1) and their indirect .144 (table 2). Their indirect effect refers to the route $\boldsymbol{\xi} \mathbf{5}^{*} \boldsymbol{\xi} \mathbf{1}$. On the other hand, there is no direct effect on profitability but only indirect effect, . 360 (tables 2 and 3). These results lead us to the acceptance of hypothesis 2. 
Complementary or Dynamic Effects

Route $\boldsymbol{\xi} \mathbf{6}$ shows a high positive but bidirectional relationship (.81) between firm assets and knowledge capabilities (figure 2), which means that an increase in one results to an increase in the other and vice versa. This verifies our hypothesis 3 partially because of the bidirectional relationship. We must stress the fact that this positive bidirectional relationship was proposed by the program (AMOS) itself after taking into consideration the raw input data of the questionnaires and its estimates that fit the proposed structural model best.

\section{The Role of Market Performance}

As it has already been discussed market performance is one of the two constructs of firm performance. The results reveal that this sustains the only factor that strategy, firm assets and knowledge capabilities affect since their impact on profitability was trivial and we find no reason even to mention its values. Market performance is influenced by all three mentioned constructs together by $89 \%$ while its own effect to profitability is $85 \%$. Thus, although strategy, firm assets, and knowledge capabilities do not influence profitability in a direct way, they manage to have a great impact on firm performance through market performance which intervenes between profitability and firm performance. 


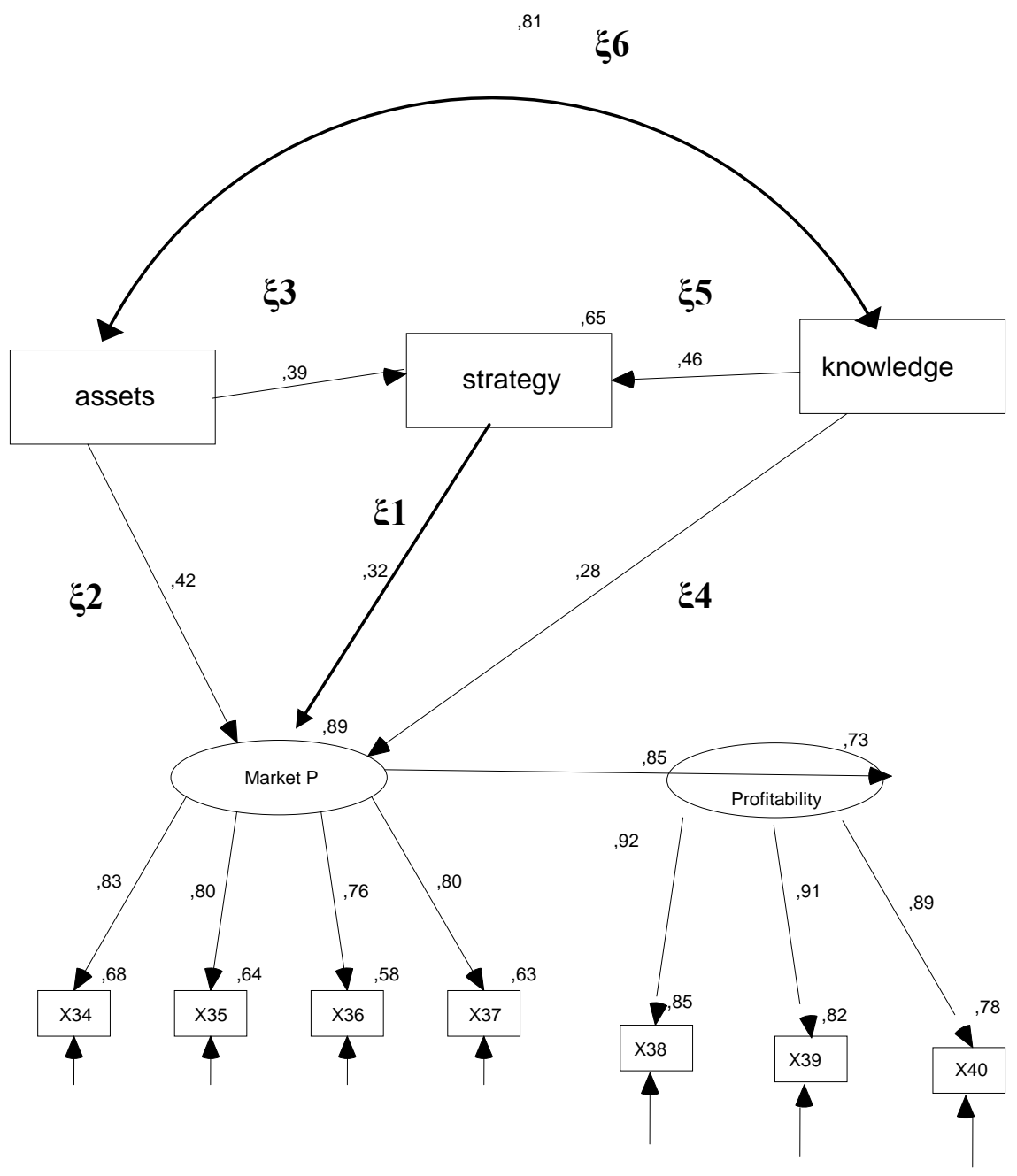

Figure 2: The Structural Model

\section{Conclusion}

Overall the results of the proposed model seem to support the need for a composite framework that takes into consideration both theories, RBV and KBV, which lead to the sustainability of firms' competitive advantage.

Furthermore, the results support the coexistence of four complementary and interrelated types of effects in determining firm's performance. These are (1) 'utility' 
type effects depending on strategy configuration, (2) 'firm-specific assets' direct (independent of strategy) and indirect (leading to the best fit of strategy to market demand and to higher customers' utility) effects, (3) 'knowledge capabilities' effects, direct and indirect, which affect the firm performance in a similar way with the firm-specific assets, and (4) 'knowledge complementary' or 'knowledge dynamic' indirect effects on firm-specific resources and capabilities, which lead to the improvement of existing or the creation of new organizational, marketing and technical capabilities. For this reason we called them 'knowledge dynamic capabilities'.

Specifically, our results lead to the following conclusions:

Strategy is a direct significant determinant of market performance and profitability (indirectly). This seems to confirm the first part of hypotheses 1 and 2, which indicates that the competitive advantage of the firms which lead to above average performance depend on strategy configuration factors. This is a necessary but not sufficient condition for above average sustainable performance, as suggested by the significance of both firm-specific assets and knowledge capabilities' effects.

Regarding firm-specific assets' effects, the results have shown a strong positive relationship between market performance and firm assets, which is actually the strongest relatively to the other two predictive constructs of strategy and knowledge capabilities. This could probably imply that the sustainability of competitive advantage depends more on the possession of unique resources and less on strategy configuration factors. These results lead us to the acceptance of hypothesis 1 .

Concerning the 'knowledge capabilities' effects on performance we notice quite strong and positive relationships. However, their effects' impact on performance is lower than that of firm-specific assets and strategy. On the other hand, there is no direct effect on profitability but only indirect effect. These results lead us to the acceptance of hypothesis 2 .

Finally, knowledge capabilities also affect performance through a second indirect 'knowledge complementary or dynamic' effect on firm specific assets. This indirect effect probably leads to the continuous improvement-renewal of the firm-specific resources and capabilities which, in turn, affect performance directly or indirectly through their affect on strategy. Consequently, these knowledge capabilities could be considered more as part of the dynamic capabilities proposed by Teece et al. (1997) and less as the 'complementary' capabilities proposed by Barney (2002), which do not have the VRIN characteristics.

A very important empirical finding of this research is the high positive and bidirectional (two way) relationship (.81) between firm assets and knowledge 
management capabilities, which means that an increase in one results to an increase in the other and vice versa. That is, as knowledge capabilities lead to the improvement of existing or the creation of new organizational, marketing and technical capabilities, these capabilities, in turn, influence knowledge by determining probably the degree and quality of KM processes (capabilities). We must stress the fact that this positive and bidirectional relationship came out of the program AMOS without our intervention. This positive relationship is very important because it empirically verifies the importance of the continuous improvement and/or the creation of new capabilities for the long term sustaining of the competitive advantage. Both of these necessary conditions, the continuous improvement and the creation of new capabilities, according to the proposed model, are primarily based, on the existence of 'knowledge management dynamic capabilities' (and, of course, the willingness of the firm to invest on this process).

To summarize, our findings indicate that apart from the direct strategy configuration direct effects both firm-specific assets and knowledge capabilities' effects contribute significantly to the creation and sustainability of competitive advantage through superior economic rents above average. This lead us to the conclusion that the two approaches of RBV and KBV do complement each other and explain better the creation and sustainability of competitive advantage.

\section{APPENDIX}

\section{CONFIRMATORY FACTOR ANALYSIS}

\section{STRATEGY}

Please indicate the extent to which you use each of the following competitive methods in your company (1: much less than its competitors...5: much more than its competitors) 
International Journal of Economics \& Business Administration, I(1)2014 $106 \quad$ N. Theriou - V. Aggelidis - G. Theriou

\begin{tabular}{|c|c|c|c|}
\hline \multicolumn{2}{|c|}{ Measures } & \multirow{2}{*}{$\begin{array}{c}\begin{array}{c}\text { First } \\
\text { Order } \\
\text { Loadings }\end{array} \\
0.76\end{array}$} & \multirow{2}{*}{$\begin{array}{c}\text { Second Order Loadings } \\
0.86\end{array}$} \\
\hline \multirow[t]{4}{*}{$\begin{array}{l}\text { Innovative } \\
\text { Differentiation }\end{array}$} & $\begin{array}{l}\mathrm{R} \& \mathrm{D} \\
\text { expenditures } \\
\text { for product } \\
\text { development }\end{array}$ & & \\
\hline & $\begin{array}{l}\text { R\&D } \\
\text { expenditures } \\
\text { for process } \\
\text { innovations }\end{array}$ & 0.78 & \\
\hline & $\begin{array}{l}\text { Emphasis on } \\
\text { being ahead of } \\
\text { competition }\end{array}$ & 0.74 & \\
\hline & $\begin{array}{l}\text { Rate of product } \\
\text { innovations }\end{array}$ & 0.79 & \\
\hline \multirow[t]{4}{*}{$\begin{array}{l}\text { Marketing } \\
\text { Differentiation }\end{array}$} & $\begin{array}{l}\text { Innovations in } \\
\text { marketing } \\
\text { techniques }\end{array}$ & 0.84 & 0.91 \\
\hline & $\begin{array}{l}\text { Emphasis on } \\
\text { marketing } \\
\text { department } \\
\text { organisation }\end{array}$ & 0.80 & \\
\hline & $\begin{array}{l}\text { Advertising } \\
\text { expenditures }\end{array}$ & 0.73 & \\
\hline & $\begin{array}{lr}\text { Emphasis on } \\
\text { strong sales } \\
\text { force }\end{array}$ & 0.75 & \\
\hline \multirow[t]{3}{*}{ Low Cost } & $\begin{array}{l}\text { Modernisation } \\
\text { and automation } \\
\text { of production } \\
\text { processes }\end{array}$ & 0.63 & 0.91 \\
\hline & $\begin{array}{l}\text { Efforts } \\
\text { achieve } \\
\text { economies of } \\
\text { scale }\end{array}$ & 0.74 & \\
\hline & $\begin{array}{l}\text { Capacity } \\
\text { utilisation }\end{array}$ & 0.65 & \\
\hline
\end{tabular}


The Mediating Effect of the Knowledge Management Process to the Firm's Performance:

\section{FIRM ASSETS}

Please indicate for each of the following competences your firm's strength relative to competition (1: much weaker than its competitors...much stronger than its competitors)

\begin{tabular}{|c|c|c|c|}
\hline \multicolumn{2}{|c|}{ Measures } & \multirow{2}{*}{$\begin{array}{l}\begin{array}{l}\text { First } \\
\text { Order } \\
\text { Loadings }\end{array} \\
0.71\end{array}$} & \multirow{2}{*}{$\begin{array}{l}\begin{array}{l}\text { Second } \\
\text { Loadings }\end{array} \\
0.85\end{array}$} \\
\hline \multirow{7}{*}{$\begin{array}{l}\text { Organizational/ } \\
\text { Managerial }\end{array}$} & Managerial competences & & \\
\hline & Knowledge and skills of employees & 0.70 & \\
\hline & Firm climate & 0.73 & \\
\hline & Efficient organisational structure & 0.78 & \\
\hline & Coordination & 0.71 & \\
\hline & Strategic planning & 0.75 & \\
\hline & Ability to attract creative employees & 0.68 & \\
\hline \multirow[t]{4}{*}{ Marketing } & Market knowledge & 0.74 & 0.92 \\
\hline & $\begin{array}{l}\text { Control and access to distribution } \\
\text { channels }\end{array}$ & 0.79 & \\
\hline & $\begin{array}{c}\text { Advantageous relationships with } \\
\text { customers }\end{array}$ & 0.47 & \\
\hline & Customers "installed base" & 0.61 & \\
\hline \multirow[t]{3}{*}{ Technical } & $\begin{array}{l}\text { Efficient and effective production } \\
\text { department }\end{array}$ & 0.77 & 0.83 \\
\hline & $\begin{array}{l}\text { Economies of scales and technical } \\
\text { experience }\end{array}$ & 0.85 & \\
\hline & $\begin{array}{c}\text { Technological capabilities and } \\
\text { equipment }\end{array}$ & 0.67 & \\
\hline
\end{tabular}


International Journal of Economics \& Business Administration, I(1)2014

\section{PERFORMANCE}

\begin{tabular}{|c|c|c|}
\hline Market & Sales volume & 0.97 \\
\hline & Growth in sales volume & 0.92 \\
\hline & Market share & 0.94 \\
\hline & Growth in market share & 0.94 \\
\hline Profitability & Return on equity & 0.99 \\
\hline & Return on own capital & 0.99 \\
\hline & Net profits & 0.98 \\
\hline
\end{tabular}


The Mediating Effect of the Knowledge Management Process to the Firm's Performance:

A Resource-Based View

\section{KNOWLEDGE MANAGEMENT}

Please indicate for each of the following knowledge capabilities your firm's strength relative to competition (1: much weaker than its competitors...much stronger than its competitors)

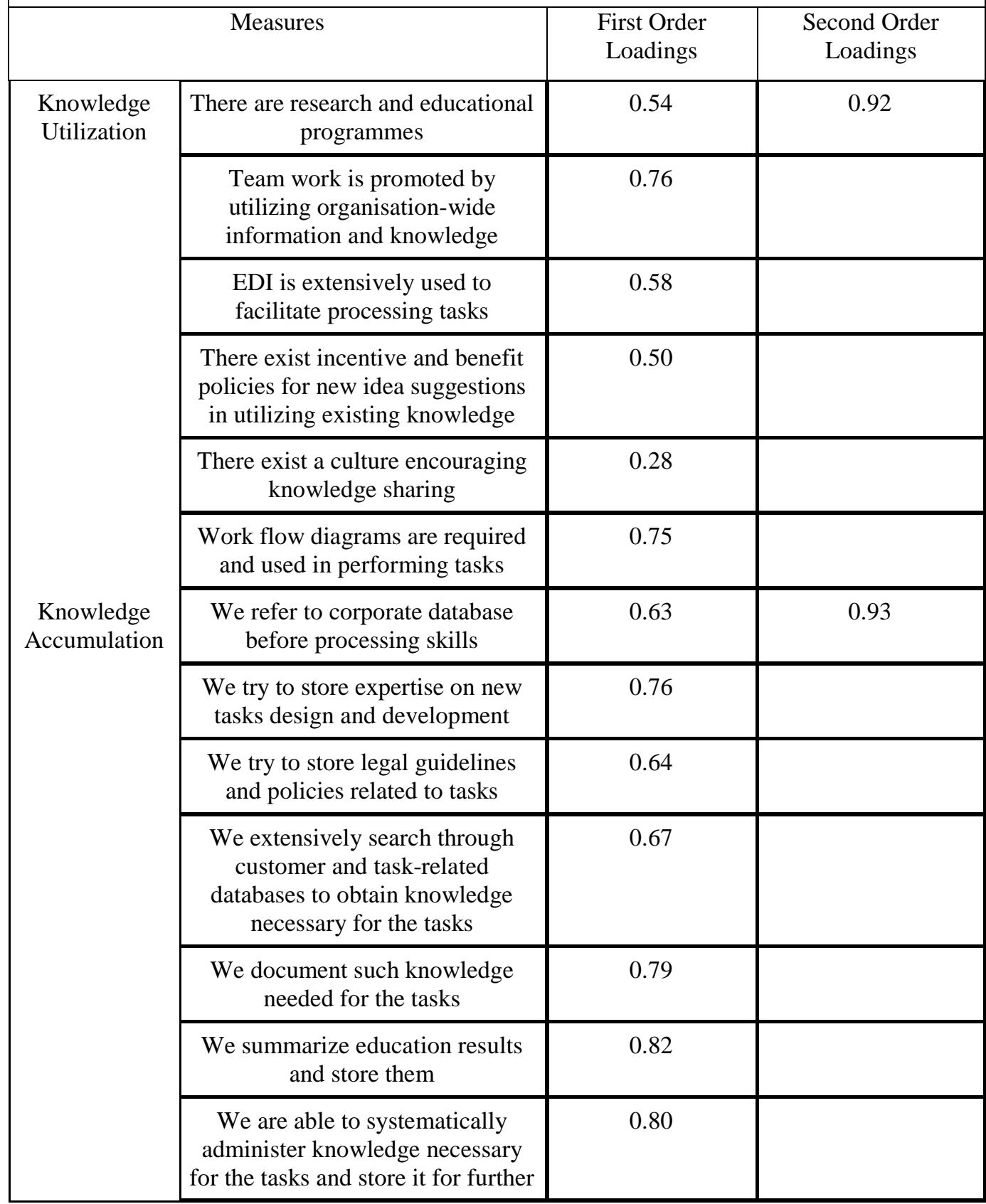


International Journal of Economics \& Business Administration, I(1)2014

$N$. Theriou - V. Aggelidis - G. Theriou

\begin{tabular}{|c|c|c|c|}
\hline \multirow{7}{*}{$\begin{array}{l}\text { Knowledge } \\
\text { internalization } \\
\text { by education } \\
\text { opportunity } \\
\text { and } \\
\text { organisational } \\
\text { learning }\end{array}$} & usage & & \\
\hline & $\begin{array}{l}\text { I have a unique mastery of the } \\
\text { tasks }\end{array}$ & 0.46 & 0.98 \\
\hline & $\begin{array}{l}\text { Professional knowledge such as } \\
\text { customer knowledge and demand } \\
\text { forecasting is managed } \\
\text { systematically }\end{array}$ & 0.70 & \\
\hline & $\begin{array}{l}\text { Organisation-wide standards for } \\
\text { information resources are built }\end{array}$ & 0.68 & \\
\hline & $\begin{array}{l}\text { Employees are given educational } \\
\text { opportunities to improve } \\
\text { adaptability to new tasks }\end{array}$ & 0.74 & \\
\hline & $\begin{array}{l}\text { University-administered education } \\
\text { is offered to enhance employees' } \\
\text { ability to perform tasks }\end{array}$ & 0.69 & \\
\hline & $\begin{array}{c}\text { Organisation-wide knowledge and } \\
\text { information are updated regularly } \\
\text { and maintained well }\end{array}$ & 0.73 & \\
\hline \multirow{3}{*}{$\begin{array}{l}\text { Knowledge } \\
\text { internalization } \\
\text { by task-related } \\
\text { knowledge }\end{array}$} & $\begin{array}{l}\text { I can learn what is necessary for } \\
\text { new tasks }\end{array}$ & 0.67 & 0.79 \\
\hline & $\begin{array}{l}\text { I can refer to best practises and } \\
\text { apply them to my tasks }\end{array}$ & 0.82 & \\
\hline & $\begin{array}{l}\text { I can use the internet to obtain } \\
\text { knowledge for the tasks }\end{array}$ & 0.64 & \\
\hline \multirow[t]{4}{*}{$\begin{array}{l}\text { Knowledge } \\
\text { sharing }\end{array}$} & $\begin{array}{l}\text { We share information and } \\
\text { knowledge necessary for the tasks }\end{array}$ & 0.69 & 0.82 \\
\hline & $\begin{array}{l}\text { We improve task efficiency by } \\
\text { sharing information and } \\
\text { knowledge }\end{array}$ & 0.70 & \\
\hline & $\begin{array}{l}\text { We developed information } \\
\text { systems, like intranet and } \\
\text { electronic bulletin boards, to share } \\
\text { information and knowledge }\end{array}$ & 0.34 & \\
\hline & $\begin{array}{l}\text { We promote sharing of } \\
\text { information and knowledge with } \\
\text { other teams }\end{array}$ & 0.58 & \\
\hline Knowledge & I often use an electronic bulletin & 0.45 & 0.89 \\
\hline
\end{tabular}


The Mediating Effect of the Knowledge Management Process to the Firm's Performance: A Resource-Based View

\begin{tabular}{|c|c|c|c|}
\hline \multirow{3}{*}{$\begin{array}{l}\text { creation by } \\
\text { task } \\
\text { understandings }\end{array}$} & board to analyse tasks & & \\
\hline & $\begin{array}{l}\text { My predecessor adequately } \\
\text { introduced me to my tasks }\end{array}$ & 0.47 & \\
\hline & $\begin{array}{l}\text { I fully understand the core } \\
\text { knowledge necessary for my tasks }\end{array}$ & 0.36 & \\
\hline \multirow[t]{4}{*}{$\begin{array}{l}\text { Knowledge } \\
\text { creation by } \\
\text { information } \\
\text { understandings }\end{array}$} & $\begin{array}{l}\text { I obtain useful information and } \\
\text { suggestions from brainstorming } \\
\text { meetings without spending to } \\
\text { much time }\end{array}$ & 0.55 & 0.86 \\
\hline & $\begin{array}{l}\text { I search information for tasks from } \\
\text { various knowledge sources } \\
\text { administered by the organisation }\end{array}$ & 0.54 & \\
\hline & $\begin{array}{l}\text { I understand computer } \\
\text { programmes needed to perform the } \\
\text { tasks and use them well }\end{array}$ & 0.41 & \\
\hline & $\begin{array}{l}\text { I am ready to accept new } \\
\text { knowledge and apply it to my } \\
\text { tasks when necessary }\end{array}$ & 0.48 & \\
\hline
\end{tabular}

\section{References}

Acedo, F. J., Barroso C. and Galan J.L., (2006), "The Resource-Based Theory: Dissemination and Main Trends", Strategic Management Journal 27 (7), pp. 621-636.

Ahlgren, P., Jarneving P.B. and Rousseau R., (2003), "Requirements for a Cogitation Similarity Measure, with Special Reference to Pearson's Correlation Coefficient", Journal of the American Society for Information Science and Technology 54 (6), pp. $550-560$.

Alavi, M. and Leidner D.E., (2001), "Review: Knowledge Management and Knowledge Management Systems: Conceptual Foundations and Research Issues", MIS Quarterly 25 (1), pp. 107-136.

Alchian, A.A. and Demsetz H., (1972), "Production, Information Costs and Economic Organization", American Economic Review 62 (5), pp. 777-795.

Amit, R. and Schoemaker P., (1993), "Strategic Assets and Organizational Rent", Strategic Management Journal 14 (1), pp. 33-46.

Barney, J.B., (1986), "Strategic Factor Markets: Expectations, Luck and Business Strategy", Management Science 32 (10), pp. 1231-1241.

Barney, J.B., (1991), "Firm Resources and Sustained Competitive Advantage", Journal of Management 17 (1), pp. 99-120.

Barney, J.B., (1996), “The Resource-Based Theory of the Firm”, Organization Science 7 (5), pp. $469-496$ 
Barney, J.B., (2001), "Resource-Based Theories of Competitive Advantage: a Ten-Year Retrospective on the Resource-Based View", Journal of Management 27 (6), pp. 643650.

Barney, J.B., (2002), "Gaining and Sustaining Competitive Advantage”, Prentice-Hall, Upper Saddle River, New Jersey.

Collis, D., (1994), "Research Note: How Valuable Organizational Capabilities are?", Strategic Management Journal 15 (Winter Special Issue), pp. 143-152.

Conner, K.R., (1991), "A Historical Comparison of Resource-Based Theory and Five Schools of Thought within Industrial Organization Economics: Do We Have a New Theory of the Firm?", Journal of Management 17 (1), pp. 121-154..

Croom, S. and Batchelor J., (1997), "The Development of Strategic Capabilities- An Interaction View”, Integrated Manufacturing Systems 8 (5), pp. 299-312.

Davenpor, T. and Prusak L., (1998), "Working Knowledge: How Organizations Manage What They Know", Harvard Business School Press, Boston.

Dess, G. and Davis P. (1984), "Porter's (1980) Generic Strategies as Determinants of Strategic Group Membership and Organizational Performance", Academy of Management Journal 27 (3), pp. 467-488.

Dyer, J.H., (1996), "Specialized Supplier Networks as a Source of Competitive Advantage: Evidence from the Auto Industry", Strategic Management Journal 17 (4), pp. 271-291.

Grant, R.M., (1996), "Toward a Knowledge-Based Theory of the Firm", Strategic Management Journal 17 (Winter Special Issue), pp. 109-122.

Hansen, G. and Wernerfelt B. (1989), "Determinants of Firm Performance: The Relative Importance of Economic and Organizational Factors", Strategic Management Journal 10 (5), pp. 399- 411.

Hoskisson, R.E., Hitt M.A.,Wan W.P. and Yiu D., (1999), "Theory and Research in Strategic Management", Journal of Management 25 (3), pp. 417-456.

Huber, G.P., (1991), "Organizational Learning: The Contributing Processes and Literatures", Organization Science 2 (1), pp. 71-87.

Kale, P. and Singh H., (1999), "Alliance Capability and Success: A Knowledge-based Approach", Academy of Management Proceedings.

Kaplan, S., Schenkel A., Von Krogh G. and Weber C., (2001), "Knowledge-Based Theories of the Firm in Strategic Management: A Review and Extension”, MIT Sloan Working Paper no. 4216-01.

Kogut, B. and Zander U., (1992), "Knowledge of the Firm, Combinative Capacities and the Replication of Technology), Organization Science 3 (3), pp. 383-397.

Lee, K.C., Lee S. and Kang I.W., (2005), "KMPI: Measuring Knowledge Management Performance", Information and Management 42 (3), pp. 469-482.

Leonard-Barton, D., (1992), "Core Capabilities and Core Rigidities: A Paradox in Managing New Product Development”, Strategic Management Journal 13 (1), pp. 111-125.

Liebowitz, J., (2000), "Building Organizational Intelligence: A Knowledge Management Primer", CRC Press, Boca Raton, FL.

Macher, J.T. and Mowery D.C., (2006), "Measuring Dynamic Capabilities: Practices and Performance in Semiconductor Manufacturing", Paper presented at 'the Practice of Dynamic Capabilities Workshop', Lancaster, UK

Makadok, R., (2001), "Toward a Synthesis of the Resource-Based and Dynamic-Capability Views of Rent Creation”, Strategic Management Journal 22 (5), pp. 387-401. 
Mahoney, J.T., (2001), “A Resource-Based Theory of Sustainable Rents", Journal of Management 27 (6), pp. 651-660.

Mahoney, J. and Pandian J., (1992), "The Resource-Based View within the Conversation of Strategic Management”, Strategic Management Journal 13 (5), pp. 363- 380.

Metaxiotis, K., Ergazakis K. and Psarras J., (2005), "Exploring the World of Knowledge Management: Agreements and Disagreements in the Academic/ Practitioner Community", Journal of Knowledge Management 9 (2), pp. 6-18.

Miller, D., (2002), "Knowledge Inventories and Managerial Myopia", Strategic Management Journal 23 (8), pp. 689-706.

Narasimha, S., (2000), "Organizational Knowledge, Human Resource Management and Sustained Competitive Advantage: Toward a Framework", Competitiveness Review 10 (1), pp. 123-135.

Nielsen, A.P., (2006), "Understanding Dynamic Capabilities through Knowledge Management", Journal of Knowledge Management 10 (4), pp. 59-71

Nonaka, I. and Takeuchi H., (1995), "The Knowledge-Creating Company. How Japanese Companies Create the Dynamics of Innovation", Oxford University Press, New York.

Pemberton, J.D. and Stonehouse G.H., (2000), "Organizational Learning and Knowledge Assets-An Essential Partnership", The Learning Organization 7 (4), pp. 184-193.

Phelan, S.E. and Lewin P., (2000), "Arriving at a Strategic Theory of the Firm”, International Journal of Management Reviews 2 (4), pp. 305-323.

Powell, T.C. and Dent-Micallef, A., (1997), "Information Technology as Competitive Advantage: The Role of Human, Business and Technology Resources", Strategic Management Journal 18 (5), pp. 375-405.

Raft, A. and Lord M., (2002), "Acquiring New Technologies and Capabilities: A Grounded Model of Acquisition Implementation", Organization Science 13 (4), pp. 420-441.

Rumelt, R., (1987), "The Competitive Challenge", Ballinger, Cambridge.

Schmalensee, R., (1985), “Do Markets Differ Much?”, American Economic Review 75 (3), pp. 341-351.

Sher, P. and Lee V.C., (2004), "Information Technology as a Facilitator for Enhancing Dynamic Capabilities through Knowledge Management", Information and Management 41 (8), pp. 933-945.

Simon, H.A., (1991), "Bounded rationality and Organizational Learning", Organization Science 2 (1), pp. 125-134.

Spanos, Y.E. and Lioukas S., (2001), "An Examination into the Causal Logic of Rent Generation: Contrasting Porter's Competitive Strategy Framework and the ResourceBased Perspective", Strategic Management Journal 22 (10), pp. 907-934.

Spender, J.C., (1996), "Making Knowledge the Basis of a Dynamic Theory of the Firm", Strategic Management Journal 17 (Winter Special Issue), pp. 45-62.

Teece, D.J., Pinsno G. and Shuen A., (1991), "Dynamic Capabilities and Strategic Management", Working paper, Centre for Research in Management, Berkley.

Teece, D.J., Pisano G. and Shuen A., (1997), "Dynamic Capabilities and Strategic Management”, Strategic Management Journal 18 (7), pp.509-533.

Thalassinos, I.E., K. Havlíček and Berezkinova, L. (2012), "Innovation Management and Controlling in SMEs", European Research Studies Journal, Vol. XV(4) Special Issue in SME's, 110-123. 
Thalassinos, I.E. and Zampeta, V. (2012), "How Corporate Governance and Globalization Affect the Administrative Structure of the Shipping Industry", Journal of Global Business and Technology, Vol. 8(1), 48-52.

Venkatraman, N. and Ramanujam V., (1986), "Measurement of Business Performance in Strategy Research: A Comparison of Approaches", Academy of Management Review 11 (4), pp. 801-814.

Wernerfelt, B., (1984), “A Resource-Based View of the Firm”, Strategic Management Journal 5 (2), pp. 171-180.

Williamson, O.E., (1999), "Strategy Research: Governance and Competence Perspectives", Strategic Management Journal 20 (12), pp. 1087-1108.

Woo, C. and Willard G., (1983), "Performance representation in business policy research: discussion and recommendation", Paper presented at the $23^{\text {rd }}$ Annual National Meeting of the Academy of Management, Dallas, Texas.

Zander, V. and Kogut B., (1995), "Knowledge and the Speed of the Transfer and Imitation of Organizational Capabilities: An Empirical Test", Organization Science 6 (1), pp. 76-91.

Zitt, M. and Bassecoulard E., (1996), "Reassessment of Co-Citation Methods for science Indicators: Effect of Methods Improving Recall Rates", Scientometrics 37 (2), pp. 223244.

Zollo, M. and Winter, S.G., (2002), "Deliberate Learning and the Evolution of Dynamic Capabilities”, Organization Science 13 (3), pp. 339-351. 